\title{
Physalis alkekengi var. franchetii extracts exert anti- tumour effects on non-small cell lung cancer and multiple myeloma by inhibiting STAT3 signalli
}

\section{Yufei Fu}

Zhejiang Chinese Medical University

Fanfan Zhu

Zhejiang Chinese Medical University

Zhongjun Ma

Zhejiang University

\section{Bin Lv}

Zhejiang Chinese Medical University

Xi Wang

Zhejiang Chinese Medical University

\section{Chunyan Dai}

Zhejiang Chinese Medical University

\section{Xiaoqiong Ma}

Zhejiang Chinese Medical University

Pei Liu

Zhejiang Chinese Medical University

Hang Lv

Zhejiang Chinese Medical University

Xin Chen

Zhejiang University

\section{Li Shen}

China Academy of Chinese Medical Sciences

Zhe Chen ( $\nabla$ chenzhe2007@zcmu.edu.cn )

\section{Research}

Keywords: Physalis, Apoptosis, Non-Small-Cell-Lung Carcinoma, Multiple myeloma, STAT3

Posted Date: June 15th, 2020

DOI: https://doi.org/10.21203/rs.3.rs-35356/v1 
License: (c) (i) This work is licensed under a Creative Commons Attribution 4.0 International License. Read Full License 


\title{
Physalis alkekengi var. franchetii extracts exert anti-tumour effects on
}

\section{non-small cell lung cancer and multiple myeloma by inhibiting}

\section{STAT3 signalling}

Yufei Fu ${ }^{1}$, Fanfan Zhu ${ }^{1}$, Zhongjun Ma ${ }^{3}$, Bin Lv ${ }^{1}$, Xi Wang ${ }^{1}$, Chunyan Dai ${ }^{1}$, Xiaoqiong Ma ${ }^{1}$, Pei Liu ${ }^{1}$, Hang Lv ${ }^{1}$, Xin Chen ${ }^{4}$, Li Shen ${ }^{2 *}$ and Zhe Chen ${ }^{1 *}$

\section{* Correspondence to:}

Prof. Li Shen: Institute of Basic Theory of Chinese Medicine, China Academy of Chinese Medicine Science, 16 Nanxiao Street, Dongzhimennei, Dongcheng Distract, Beijing, China, Tel: +86-18611325278, Email: shenli1116@126.com

Prof. Zhe Chen: Key Laboratory of Digestive Pathophysiology of Zhejiang Province, First Affiliated Hospital, Zhejiang Chinese Medical University, 548 Binwen Road, Hangzhou 310053, China, Tel: +86-571-86620280, Email: chenzhe2007@zcmu.edu.cn

\begin{abstract}
Background: Physalis alkekengi var. franchetii is an herb that possesses various ethnopharmacological applications. Herein, our current study focuses on the anti-tumour effect of the combination of various physalins, which are regarded as the most representative secondary metabolites from calyces of Physalis alkekengi var. franchetii.
\end{abstract}

Methods: We mainly investigated the anti-tumour activity of the physalins extracted from Physalis alkekengi var. franchetii on both solid and haematologic cancers. The main cells used in this study were NCI-H1975 and U266 cells. The major assays used were the CCK8 assay, western blot analyses, an immunofluorescence assay, the Annexin V assay, and xenograft mouse model.

Results: The results showed that physalins exhibited strong anti-tumoural effect on both non-small cell lung cancer (NSCLC) and multiple myeloma (MM) cells by suppressing the constitutive STAT3 activity and further inhibiting the downstream target genes expression of STAT3 signalling, resulting in the enhanced apoptosis of tumour cells. Moreover, physalins significantly reduced tumour growth in xenograft models of lung cancer.

Conclusions: Collectively, these findings demonstrated that the physalins from Physalis alkekengi var. franchetii may potentially act as chemopreventive or chemotherapeutic agents for NSCLC and MM by inhibiting the STAT3 signalling pathway. It is promising that the present study served as a guide to further explore the precise mechanism of Physalis alkekengi var. franchetii in cancer treatment.

keywords: Physalis, Apoptosis, Non-Small-Cell-Lung Carcinoma, Multiple myeloma, STAT3 


\section{Background}

Physalis alkekengi L. (also known as "Jindenglong") is a well-known traditional Chinese medicinal herb, which is the dried calyces or calyces-with-fruit of $P$. alkekengi var. franchetii (Solanaceae) [1]. It is widely used for the treatment and prevention of different diseases, including sore throat, cough, eczema, tonsillitis, pharyngitis, hepatitis, leishmaniasis and tumours [2]. Recently, several studies show that it plays a critical role in anti-tumour, anti-oxidant, anti-bacterial, anti-inflammatory, immunomodulation and cytotoxic functions [3-8]. The main chemical conponents of Physalis alkekengi L. are physalins, neophysalins, alkaloids, polysaccharides and flavonoids, among which physalins are known as the most bioactive substances [9]. Physalins were evaluated for their therapeutic potential and were found to possess anti-inflammatory, immunomodulatory and anti-tumour properties. For example, in human melanoma cells, physalin B can induce apoptosis by increasing the protein levels of Bax and caspase-3 [10]. Human renal cancer cells were inhibited by physalin $F$ through inducing reactive oxygen species (ROS)-mediated apoptosis [11]. Physalin D, another active component, possesses an anti-oxidant activity [12]. Additionally, physalin A exerts anti-tumour activities on NSCLC by suppressing the JAK/STAT3 signalling pathway [4]. However, whether the mixture of physalins from Physalis alkekengi L. inhibits non-small cell lung cancer (NSCLC) and multiple myeloma (MM), a solid and haematologic cancer, respectively, still remains obscure.

As previously reported, michael reaction acceptors (MARs) are a kind of active molecules which may have antitumor activity. Five physalins were investigated might be MARs and have antitumor activity [13]. In present study, we attempted to investigate the possible molecular and cellular mechanism of $P$. alkekengi var. franchetii extracts on the growth and apoptosis of NSCLC (NCI-H1975) and MM cell lines (U266). Moreover, the anti-tumour activity of P. alkekengi var. franchetii extracts on lung cancer was also evaluated in the xenograft mouse model to assess the efficacy and toxicity of physalins.

\section{Matierials and Methods}

\section{Plant Material}

The Physalis alkekengi var. franchetii (Lot No. 151227) used in this study was purchased from the Huadong Chinese crude Co. According to the Zhejiang traditional Chinese medicine processing standard (2005 Edition, QS-01-0000-03), the Physalis alkekengi var. franchetii used in this study passed standard tests (Report No. C151229-6). The authentication of the herb was also performed by chief pharmacist Min Xia Zheng of the Zhejiang provincial Hospital of TCM, China. The Huadong Chinese crude Co. is one of the designated clinical herb suppliers (Supplementary Table 1). 


\section{Extraction}

The extraction methods were previously described [13]. Eight-fold 95\% EtOH under reflux was used to extract dried calyces $(10 \mathrm{~kg})$ of Physalis alkekengi var. franchetii for three times. After vacuum drying, about $830 \mathrm{~g}$ of extract was obtained. The extract was resoluted in water $(1 \mathrm{~L})$ and then extracted three times with petroleum ether $(1 \mathrm{~L})$ and dichloromethane $(1 \mathrm{~L})$. The dichloromethane fraction $(160 \mathrm{~g})$ was obtained finally.

\section{Quality control of Physalis alkekengi var. franchetii}

Five physalins were separated and identified from the calyces of Physalis alkekengi var. franchetii in our previous study [13]. The extract contents of Physalis alkekengi var. franchetii were determinated by chromatographic analyses performed with an Acquity UPLC system (Waters, Milford, MS, USA) and a BEH C18 column $(2.1 \mathrm{~mm} \times 100 \mathrm{~mm} \times 1.7 \mu \mathrm{m})$. MS and MS-MS detections was done on a Micromass Quattro Premier tandem quadrupole mass spectrometer (Waters, Manchester, UK) using an electrospray (ESI) source in positive mode. The method was previously reported with minor modifications [13]. One hundred milligrams of pulverized sample was accurately weighed and was then transferred to a $50 \mathrm{~mL}$ volumetric flask and diluted with methanol to a volume of $50 \mathrm{~mL}$. Finally, both of the test samples were filtered through a $0.45 \mu \mathrm{M}$ membrane filter prior to UPLC analysis. The parameters of UPLC were as previously reported [13].

\section{Tumour cell lines}

Seven human tumour cell lines, including NCI-H1975, H292, H358, U266, MKN45, MCF-7, and SW620, were perchased from Type Culture Collection of Chinese Academy of Sciences (Shanghai, China). All these cells were cultured in RPMI-1640 medium (Thermo Fisher Scientific, Waltham, MA, USA) with 10\% fetal bovine serum (FBS; Thermo Fisher Scientific, Waltham, MA, USA).

\section{Cell viability}

The tumour cell growth was quantified by the Cell Counting Kit-8 (CCK-8; DOJINDO) assay according to the manufacturer's instructions [14]. Briefly, the cells were plated in a 96-well plate $\left(0.6 \times 10^{5}\right.$ cells/well $)$ and incubated with $100 \mu \mathrm{L}$ of medium overnight. The cells were treated with different concentrations of physalins $(0,2.5,5,10,15,20,30 \mu \mathrm{g} / \mathrm{mL})$ for $24 \mathrm{~h}$ or $48 \mathrm{~h}$. The absorbance at $450 \mathrm{~nm}$ using a microplate spectrophotometer (Varioskan Flash, Thermo Fisher Scientific) after culturing the cells with $10 \mu \mathrm{L}$ of CCK- 8 reagent for about 2 hours. The IC50 value was used to evaluate the cytotoxicity of a drug which is needed for $50 \%$ growth inhibition in vitro. The IC50 value was calculated by the fitted line $(\mathrm{Y}=\mathrm{a} \times \mathrm{X}+\mathrm{b})$.

\section{Western blot analysis}

Cold lysis buffer (150 mM NaCl, 1\% NP-40, $50 \mathrm{mM}$ Tris-HCL, pH 8.0, supplemented with complete set of protease inhibitors; Roche) was added to the treated NCI-H1975 and U266 cells. After centrifugation and concentration 
qualification, the whole protein extracts were mixed with loading buffer and then boiled for $10 \mathrm{~min}$. After separating by SDS-PAGE, the proteins were transferred to PVDF membranes. 5\% BSA was used for blocking. The primary antibodies were against STAT3, p-STAT3-Tyr, p-STAT3-Ser, Mcl-1, Bcl-2, Bcl-xL, survivin, cleaved caspased-3, cleaved caspase-9 and PARP (1:1000, Cell Signaling Technology, Beverly, MA, USA), $\beta$-Actin (1:3000 dilution, Sigma-Aldrich, Merck KGaA, St Louis, MO, USA). Membranes were then incubated with secondary antibodies (1:8000 dilution, Lianke Bio, P.R. China). The immunoreactive proteins were detected using a chemiluminescent immunodetection system (ChemiDocTM XRS). The semi-quantification of protein levels were performed by Image $\mathrm{J}$ software. The quantifications were shown by the relative gray values, as a ratio of each protein band relative to the lane's loading control. All the values were then analyzed by GraphPad Prism5 and shown in bars. * for $P<0.05, * *$ for $P<0.01$ and $* * *$ for $P<0.001$.

\section{Apoptosis detection assay}

The different cells $\left(1 \times 10^{5}\right.$ per well $)$ mentioned above were seeded overnight on 12-well plates until $70 \%$ confluence, and then was treated with various concentrations of physalins $(0,5,10$, and $15 \mu \mathrm{g} / \mathrm{mL})$ for $24 \mathrm{~h}$, as the control group was treated with DMSO. After trypsinizing, the cells were washed twice with cold PBS and were then mixed with binding buffer with anti-Annexin V-FITC/PI for 15 min according to the manufacturer's instructions. Then the apoptotic cells were evaluated using a FACS CantoII flow cytometer (BD Pharmingen) and the FlowJo software (TreeStarInc).

\section{Immunofluorescence}

The $\mathrm{H} 1975$ cells are treated with $15 \mu \mathrm{M}$ physalins for $6 \mathrm{~h}$ followed by treating with recombinated IL-6 proetin $(25 \mathrm{ng} / \mathrm{mL})$ to induce pYSTAT3 levels and were then fixed in $4 \%$ paraformaldehyde for $15 \mathrm{~min}$ on ice and were permeabilized with pre-cooling methanol for another $10 \mathrm{~min}$ on ice. Next, the cells were blocked with blocking solution (5\% normal goat serum, 0.3\% Triton X-100 in PBS) for 60 mins at room temperature. After aspirating the blocking solution, the diluted primary antibody p-STAT3-Tyr (1:500, Cell signalling Technology) was applied and was incubated overnight at $4{ }^{\circ} \mathrm{C}$. The next day, the slides were rinsed in PBS 3 times and incubated with a fluorochrome-conjugated secondary antibody diluted in Antibody Dilution Buffer (1\% BSA and $0.3 \%$ Triton X-100 in PBS) for $1-2 \mathrm{~h}$ away from the light. The slides were rinsed with PBS 3 times and coverslipped with Prolong ${ }^{\circledR}$ Gold Anti-Fade Reagent (\#9071; Cell Signaling) with DAPI (\#8961; Cell Signaling).

\section{Xenograft mouse model}

A total of 20 male BALB/c mice were divided into 4 groups (5 mice/group) and kept under pathogen-free conditions at room temperature $\left(21\right.$ to $\left.25^{\circ} \mathrm{C}\right)$, with exposure to light for $12 \mathrm{~h}$ and $12 \mathrm{~h}$ of dark. Food and water were offered ad libitum. $5 \times 10^{6}$ human NCI-H1975 cells were subcutaneously injected into the right front leg of 6 -weeks-old male BALB/c mice. When the tumour reached $100-150 \mathrm{~mm}^{3}, 100$ or 200 $\mathrm{mg} / \mathrm{kg} /$ day (calculated according to clinical condition and converted using formula, 
i.e., Mouse dosage $=\mathrm{X} \mathrm{mg} / \mathrm{kg} \times 70 \mathrm{~kg} \times 0.0026 / 20 \mathrm{~g}=9.1 \times \mathrm{X} \mathrm{mg} / \mathrm{kg}$ ), physalins were administered orally with CMC-Na or $5 \mathrm{mg} / \mathrm{kg} /$ day cisplatin intraperitoneally injected for 12 days. The tumour volume and body weight were assessed every two days. The tumour volume was calculated as $\mathrm{V}=$ length $\times$ width $^{2} / 2$ [15]. The mice were sacrificed by cervical dislocation in a very short time, and then the tumours were obtaine and measured. For an animal carring one tumour, the diameter should not exceed $2.0 \mathrm{~cm}$ in mice for therapeutic studies according to the guidelines from the University of Pennsylvania Institutional Animal Care and Use Committee.

\section{Statistical analysis}

The statistical calculation of differences between the means was conducted by a Student's t-tests and shown as mean \pm SD in each group. An analysis of variance (ANOVA), including the F value, was carried out with a Tukey's post hoc test for multiple comparisons. Statistical significance was considered at $P<0.05$ or $P<0.01$. All the experiments were replicated for three times.

\section{Results}

\section{Quality evaluation of Physalis alkekengi var. franchetii}

According to previous studies, physalins are identified as the main active and characteristic component of Physalis alkekengi var. franchetii [9]. Five physalins were isolated and identified from the calyces of $P$. alkekengi var. franchetii in our previous study [13]. The results from UPLC-MS also showed that the main extracts contain five physalins, including physalin $\mathrm{A}$, physalin $\mathrm{G}$, physalin $\mathrm{O}$, physalin $\mathrm{L}$, and isophysalin, of which the contents were $26.03 \%, 2.66 \%, 52.06 \%, 12.92 \%$, and $1.33 \%$ respectively (Fig. 1). However, based on a peak area normalization method, other components only occupied 5\% in the extracts, and the extracts used in this study were endotoxin free. Thus, the effects of the other components on the in vitro experiment can be ignored.

\section{Physalis alkekengi var. franchetii extracts inhibit cell viability in NCI-H1975 and U266 cells}

To evaluate the anti-tumoural activities of physalins isolated from Physalis alkekengi var. franchetii, seven human tumour cells lines (NCI-H1975, NCI-H292, NCI-H358, U266, MKN45, MCF-7, and SW620) were treated with different dosages of extracts for $24 \mathrm{~h}$ or $48 \mathrm{~h}$ and were then subjected to a CCK8 assay (Cell Counting Kit-8, DOJINDO) (Fig. 2A and B). The results showed that all the detected cell lines were sensitive to physalins, and the $50 \%$ inhibitory concentration (IC50) values of 24 $\mathrm{h}$ incubation were all less than $23 \mu \mathrm{g} / \mathrm{mL}$. In particular, physalins had a higher inhibitory effect on NCI-H1975 and U266 cells (14.342 and $11.2 \mu \mathrm{g} / \mathrm{mL}$, Table 1) and the IC50 values of these two cell lines had significant differences among other cells. Previous studies show that STAT3 is activated and is highly expressed in these two cell lines, which is reminiscent of a connection between the inhibitory mechanism of physalins and the STAT3 signalling pathway. 


\section{Physalis alkekengi var. franchetii extracts reduce the phosphorylation (Tyr705) of STAT3 in NCI-H1975 and U266 cells}

To test the above hypothesis, we initially observed the activity change in STAT3 after physalins treatment by examining the phosphorylation levels of STAT3 (Tyr705 and Ser727). NCI-H1975 and U266 cells were first administered with different concentrations of physalins treated for $4 \mathrm{~h}$. The Western blot results showed that the level of STAT3 Tyr705 phosphorylation in the physalins-treated group decreased significantly, in a concentration-dependent manner, compared with the DMSO sovent group (Fig. 3A, B). By contrast, there is no obvious difference at the Ser727 site among all the groups. Moreover, the level of total STAT3 also showed no change in both cell lines. Collectively, these results suggested that physalins suppress constitutive STAT3 Tyr705 phosphorylation in NCI-H1975 and U266 cells.

Previous reports identified that STAT3 phosphorylation at Tyr705 (pYSTAT3) leads to STAT3's nuclear translocation in response to various extracellular cytokines, such as interleukin (IL)-6[16]. So we examined whether physalins could repress the nuclear translocation of pYSTAT3 in NCI-H1975 cells. Immunofluorescence assay showed that the immunoreactivity of anti-pYSTAT3 was predominantly increased in the nucleus of IL-6-stimulated or unstimulated NCI-H1975 cells but was apparently decreased by a $15 \mu \mathrm{g} / \mathrm{ml}$ physalins treatment for $6 \mathrm{~h}$ (Fig. 3C).

\section{Physalis alkekengi var. franchetii extracts suppress the expression of STAT3-regulated genes in NCI-H1975 and U266 cells}

To further investigate whether physalins suppress STAT3-mediated downstream signalling, we detected the expression levels of target genes of STAT3, including anti-apoptotic proteins in the Bcl-2 family (Mcl-1, Bcl-2, and Bcl-xL), XIAP, and survivin by western blot analysis. The expression levels of Bcl-2 and XIAP in the NCI-H1975 and U266 cells were significantly reduced after the physalins exposure for $24 \mathrm{~h}$. Moreover, the decrease occurred in a concentration-dependent manner (Fig. $4 \mathrm{~A}, \mathrm{~B})$. The band signals of both Bcl-2 and XIAP were strongly weakened after an incubation with physalins at $15 \mu \mathrm{g} / \mathrm{mL}$. However, the expression levels of the other detected genes (Mcl-1, Bcl-xL and survivin) showed no significant difference. Therefore, these results indicated that $P$. alkekengi var. franchetii extracts further inhibited the STAT3-regulated downstream genes Bcl-2 and XIAP.

\section{Physalis alkekengi var. franchetii extracts induce apoptosis in NCI-H1975 and U266 cells}

Since Bcl-2 and XIAP are known to be the potent inhibitor of apoptosis, an Annexin V-FITC/PI assay was subsequently performed to investigate whether physalins further induce apoptosis in NCI-H1975 and U266 cells. As expected, the flow cytometry results showed that the physalins, in a concentration-dependent manner, significantly elevated apoptotic rate in the NCI-H1975 and U266 cells (Fig. 5A, B). Compared with the control groups, the proportion of apoptotic NCI-H1975 cells (upper right panel for the late stage plus the lower right panel for the early stage 
of apoptosis in Fig. 5A) increased from $6.8 \pm 1.2 \%$ to $11.5 \pm 3.1 \% \sim 58.3 \pm 6.1 \%$ after physalins treatment at doses of $5 \sim 15 \mu \mathrm{g} / \mathrm{mL}$ for $24 \mathrm{~h}$. Similarly, the percentage of apoptotic U266 cells in the physalins-treated groups $(18.6 \pm 3.6 \% \sim 43.4 \pm 10.4 \%)$ was much higher than the control group $(4.5 \pm 1.0 \%)$. Correspondingly, the apoptosis related proteins cleaved caspase 3, cleaved caspase 9 and cleaved poly (ADP-ribose) polymerase (PARP) were significantly increased in the physalins-administered groups (24 h treatment) (Fig. 5C, D). Collectively, the above results demonstrated that $P$. alkekengi var. franchetii extracts promoted apoptosis in the NCI-H1975 and U266 cells by regulating the STAT3 signalling pathway.

\section{Physalis alkekengi var. franchetii extracts inhibit tumour growth in a human NSCLC xenograft model}

Finally, NCI-H1975 xenograft models were used to evaluate the anti-tumour activity of physalins. Comparing to the control group, the tumour growth (tumour volume) was significantly inhibited in the high-dose physalins-treated group (200 $\mathrm{mg} / \mathrm{kg}$ ) and the cisplatin (DDP)-treated (5 $\mathrm{mg} / \mathrm{kg}$ ) group under the surveillance of 12 days (Fig. 6A, B). Then, the mice were sacrificed, showing that the tumour weight was reduced in the low-dose physalins-treated group $(100 \mathrm{mg} / \mathrm{kg})(P=0.0016)$ and was obviously decreased in the high-dose physalins treated group $(P<0.0001)$ and the DDP-treated group $(P=0.0003)$ (Fig. 6C). The weights of the physalins-treated groups displayed no significant difference compared with the control group, but the DDP-treated group showed weight loss $(P=0.01)$ (Fig. 6D). Taken together, the above results demonstrated that the anti-tumour activity of physalins was comparable to that of cisplatin, a chemotherapy agent, but physalins mitigate the side effect of body weight loss.

\section{Discussion}

Natural compounds derived from food, herbs and plants have been used as anti-tumour agents [17]. Population studies suggest that potential natural cancer preventive compounds are safe, practical, economical, and effective for cancer treatment [18]. For example, $P$. alkekengi var. franchetii is an herb that possesses popular interest due to its therapeutic properties [1]. Previous studies already demonstrate that several extractions from the calyces of $P$. alkekengi var. franchetii were vital in combating cancer $[4,6]$. For example, physalin A in different cencers $[4$, 19]. It inhibits tumour cell growth, promotes apoptosis and autophagy via Nrf2 signalling, JAK-STAT3 signalling or ROS generation [4, 20, 21].

In our study, the main components from the calyces of $P$. alkekengi var. franchetii extracts were five physalins, which were identified by UPLC. Physalins species are considered of great medicinal value, since these compounds display various of biological activities, such as antimicrobial, anti-tumour, anti-inflammatory, immunomodulatory, immunosuppressive, cytotoxic, trypanocidal, and molluscicidal effects [7, 22-27]. Previously, we have reported that anti-tumour growth and apoptosis-promoting effects of physalin A was depended on suppressing STAT3 
activity in NSCLC cell lines [4]. Herein, our current study focused on the anti-tumour effect of the combination of five physalins from $P$. alkekengi var. franchetii. This antitumous effect was initially evaluated in seven types of cell lines and the results showed that physalins inhibited the growth of all the tested cell lines, which suggested that physalins exhibited a non-selective anti-tumour activity. Moreover, the anti-tumour molecular mechanism of physalins was explored in vitro using representative solid tumour (NCI-H1975) and haematological tumour (U266) cell lines.

STAT3 is vital in the initiation and progression of vavious cancers, such as proliferation, anti-apoptosis, invasion and immune surveillance evasion [28-30]. It is activated by the phosphorylation of its tyrosine or serine residues via modulating upstream regulators $[31,32]$. The phosphorylation of STAT3 induces the dimerization through the interactions of reciprocal phosphotyrosine-Src homology domain 2 (SH2). Activated STAT3 dimers initiate the transcription of target genes by translocating to the nucleus and interacting with the promoter sequence [31,33]. Parent STAT3 activation is related to a wide spectrum of cancers, including NSCLC and MM, and is positively associated with a poor prognosis [34-37]. A wide range of pre-clinical studies show that phosphorylated-STAT3 (pSTAT3) is a well-known characteristic of various cancers [38-40]. Accumulating evidence shows that the constitutive STAT3 activation occurs frequently in a wide range of tumour cells, including MM and more than $22 \% \sim 65 \%$ of NSCLC [41-44]. This indicates that the aberrant STAT3 signalling is an important process in malignant progression. As such, the inhibition of STAT3 signalling is considered a novel and potential target to treat cancers.

STAT3 is activated by Tyr705 site phosphorylation in response to membrane factors such as the interleukin-6 (IL-6) [45]. It also has been shown that phosphorylation of Ser727site of STAT3 is phosphorylated by various kinds of kinases in various cancers [46-49]. However, some reports have showed that the Ser727 site phosphorylation suppresses STAT3 activity and cell proliferation [50, 51]. In our study, we reported that $P$. alkekengi var. franchetii extracts repressed Tyr705 phosphorylation of STAT3 in H1975 and U266 cells, but have no significant effect on Ser727 phosphorylation of STAT3.

In our previous study, we illustrated that physalins acted as Michael reaction factors and directly induced a rapid drop in the concentration of intracellular glutathione (GSH), thereby triggering the S-glutathionylation of STAT3 and inhibiting the tyrosine phosphorylation of STAT3 [13, 52]. In this study, P. alkekengi var. franchetii extracts inhibited the level of STAT3 tyrosine phosphorylation and further suppressed the expression of the STAT3 downstream target genes. Bcl-2 and XIAP are both anti-apoptotic proteins. Following Bcl-2 downregulated, the pro-apoptotic proteins are subsequently activated, resulting in mitochondrial outer membrane permeabilization (MOMP). Then cytochrome $\mathrm{c}$ and second mitochondria-derived activator of caspase (SMAC) released from the mitochondria, which results in the activation of caspase 9. Caspase 9 then activates procaspase 3 and procaspase 7 , leading to cell death [53]. XIAP, X-linked inhibitor of apoptosis, inhibits caspase 9 [54]. Another apoptotic marker cleaved PARP is catalyzed by caspase-3 [55]. In brief, 
P. alkekengi var. franchetii extracts inhibit STAT3-targeted anti-apoptotic proteins, which leads to the cleavage of both caspase-3 and PARP, resulting in an increased apoptosis rate in both NCI-H1975 and U266 cells. Therefore, suppressing the continuous activation of STAT3 may be an effective target for cancer therapy. It is meaningful and valuable to discover and develop effective STAT3 inhibitors as an anti-tumour component in the treatment of cancer. However, the inhibitory specificity and selectivity of physalins are still unknown, which will be further clarified by a molecule docking assay and competitive inhibition experiment.

Notably, based on the results from the in vitro experiments, including cell proliferation and apoptosis, we are aware that the effects of $P$. alkekengi var. franchetii extracts on NCI-H1975 and U266 cells are almost consistent, which suggests that physalins from $P$. alkekengi var. franchetii may have similar or identical anti-tumour activity on solid tumours as well as haematological tumours. Moreover, the anti-tumour effects of the P. alkekengi var. franchetii extracts were tested using a human xenograft model of lung cancer. Consistent with the in vitro results, the data showed that physalins from $P$. alkekengi var. franchetii inhibited tumour growth, which was embodied in a decreased tumour volume and weight in the xenograft model.

In a human NSCLC xenograft model, the body weights of the physalins-treated groups were no significantly different compared with the control group, but DDP-treated group showed weight loss. Moreover, the physalins-treated groups did not have an adverse reaction during observation, and thus, $P$. alkekengi var. franchetii extracts are safe, have a low-toxicity and no obvious side effect. Compared with the effect of Physalin A (injected intraperitoneally ) [4], Physalis alkekengi L. extracts (taken orally) are easier to take than Physalin A only. P. alkekengi L. extracts are more convenient for large-scale preparation and extraction than the isolated and purified physalin monomer. Moreover, an herbal cocktail therapy can partially reduce single drug resistance. The anti-tumor effects of other physalins and their combined inhibitory effects should be further discovered in our next paper

In summary, the $P$. alkekengi var. franchetii extracts inhibited tumour proliferation and promoted apoptosis in NSCLC and MM cells by repressing the STAT3 signalling. The findings of this study help the development of physalins from P. alkekengi var. franchetii as a promising anti-tumour drug. Clinical evaluation and application were the main limitations of our study, and these can be the future direction.

\section{Conclusions}

Collectively, our study demonstrates that the extracts from Physalis alkekengi var. franchetii have anti-tumour activities for NSCLC and MM. The results reported that the $P$. alkekengi var. franchetii extracts inhibited tumour growth and induced apoptosis in human NSCLC and MM cell lines by repressing the STAT3 signalling pathway. Besides that, physalins significantly reduced tumour growth in xenograft 
models of lung cancer without weight loss. These findings significantly imply that Physalis alkekengi var. franchetii might be a safe and promising agent for cancer treatment.

\section{Additional file}

Additional file 1. Inspection report of Physalis alkekengi var. franchetii.

\section{Abbreviations}

P. alkekengi var. franchetii: Physalis alkekengi var. franchetii; NSCLC: non-small cell lung cancer; MM: multiple myeloma; ROS: reactive oxygen species; PARP: poly (ADP-ribose) polymerase; DDP: cisplatin; GSH: glutathione

\section{Author's Contributions}

Conceived and designed the experiments: LS, ZC and YFF. Performed the experiments: YFF, FFZ, XW, CYD, PL and HL. Analysed the data: YFF, LS and XQM. Contributed reagents/materials/analysis tools: ZJM, BL, XQM, YFF and XC. YFF wrote the manuscript.

\section{Author details}

${ }^{1}$ Key Laboratory of Digestive Pathophysiology of Zhejiang Province, Insititute of Cancer Research, First Affiliated Hospital, Zhejiang Chinese Medical University, Hangzhou, China. ${ }^{2}$ Institute of Basic Theory of Chinese Medicine, China Academy of Chinese Medicine Science, Beijing, China. ${ }^{3}$ Institute of Marine Biology and Natural Products, Department of Ocean Science and Engineering, Zhejiang University, Hangzhou, China. ${ }^{4}$ Department of Thoracic and Cardiovascular Surgery, The First Affiliated Hospital of Zhejiang University, Hangzhou, China.

\section{Acknowledgements}

Not applicable.

\section{Funding:}

This work was supported by grants from the National Natural Science Foundation of China [grant numbers: 81603340, 81773945, 81802887, 81873276, 81503297, 81803776], Medical Health Science and Technology Project of Zhejiang Provincial Health Commission [grant numbers:2019RC228, 2019RC229], the Zhejiang Provincial Natural Science Foundation of China [grant numbers: LY17H280006], the Opening Project of Zhejiang Provincial First-rate Subject (Integrated Traditional and Western Medicine) of the Zhejiang Chinese Medical University [grant numbers: ZXYJH2018004]; Traditional Chinese Medicine Scientific Research Foundation of Zhejiang Province [grant numbers: 2018ZB044].

\section{Conflict of interests}

The authors declare that they have no conflict of interests. 


\section{Availability of data and materials}

The materials and data of this study are available to other researchers upon request.

\section{Consent for publication}

All authors have provided consent for publication in the journal of Chinese Medicine.

\section{Ethics approval and consent to participate}

This study was carried out in accordance with the local guidelines for the care of laboratory animals of the Animal Experimental Center, Zhejiang Academy of Medical Sciences and was approved by the ethics committee for research on laboratory animal use of the Zhejiang Chinese Medical University (No.2015-006A).

\section{Reference}

Reference

1. Guo Y, Liu H, Ding L, Oppong M, Pan G, Qiu F. LC-MS/MS method for simultaneous determination of flavonoids and physalins in rat plasma: application to pharmacokinetic study after oral administration of Physalis alkekengi var. franchetii (Chinese lantern) extract. Biomedical chromatography : BMC 2017; doi 10.1002/bmc.3970.

2. Zhang L, Ding AW. On the Subsequent Revision of Pharmacopoeia of the People's Republic of China: Volume I (2010 Edition)——Based on the Regulation of Crude Drugs Standard in the Japanese Pharmacopoeia(16th Edition). Journal of Nanjing University of Traditional Chinese Medicine 2012; 28(4): 301-365.

3. Wang ZY, Ting-Ting SU, Ning LI. Study on extraction and antimicrobial activity of extracts from physalis alkekengil I. var. francheti(mast.) makino. Food Science \& Technology 2009.

4. Zhu F, Dai C, Fu Y, Loo JF, Xia D, Gao SP et al. Physalin A exerts anti-tumor activity in non-small cell lung cancer cell lines by suppressing JAK/STAT3 signaling. Oncotarget 2016; 7(8): 9462-9476.

5. Kang H, Kwon SR, Choi HY. Inhibitory effect of Physalis alkekengi L. var. franchetii extract and its chloroform fraction on LPS or LPS/IFN- $\gamma$-stimulated inflammatory response in peritoneal macrophages. Journal of ethnopharmacology 2011; 135(1): 95-101.

6. Magalhães HI, Veras ML, Torres MR, Alves AP, Pessoa OD, Silveira ER et al. In-vitro and in-vivo antitumour activity of physalins $B$ and D from Physalis angulata. Journal of Pharmacy \& Pharmacology 2006; 58(2): 235-241.

7. Soares MB, Bellintani MC, Ribeiro IM, Tomassini TC, Ribeiro dSR. Inhibition of macrophage activation and lipopolysaccaride-induced death by seco-steroids purified from Physalis angulata $\mathrm{L}$. European journal of pharmacology 2003; 459(1): 107.

8. Castro DP, Figueiredo MB, Ribeiro IM, Tomassini TC, Azambuja P, Garcia ES. Immune depression in Rhodnius prolixus by seco-steroids, physalins. Journal of insect physiology 2008; 54(3): 555-562; doi 10.1016/j.jinsphys.2007.12.004.

9. Zheng Y, Chen Y, Ren Y, Luan L, Wu Y. Quantitative and transformation product analysis of major active physalins from Physalis alkekengi var. franchetii (Chinese lantern) using ultraperformance liquid chromatography with electrospray ionisation tandem mass spectrometry and time-of-flight mass spectrometry. Phytochemical analysis : PCA 2012; 23(4): 337-344. 
10. Hsu CC, Wu YC, Farh L, Du YC, Tseng WK, Wu CC et al. Physalin B from Physalis angulata triggers the NOXA-related apoptosis pathway of human melanoma A375 cells. Food and chemical toxicology : an international journal published for the British Industrial Biological Research Association 2012; 50(3-4): 619-624.

11. Wu SY, Leu YL, Chang YL, Wu TS, Kuo PC, Liao YR et al. Physalin F induces cell apoptosis in human renal carcinoma cells by targeting NF-kappaB and generating reactive oxygen species. PloS one 2012; 7(7): e40727.

12. Helvaci S, Kokdil G, Kawai M, Duran N, Duran G, Guvenc A. Antimicrobial activity of the extracts and physalin $D$ from Physalis alkekengi and evaluation of antioxidant potential of physalin $D$. Pharmaceutical biology 2010; 48(2): 142-150.

13. Ji L, Yuan Y, Luo L, Chen Z, Ma X, Ma Z et al. Physalins with anti-inflammatory activity are present in Physalis alkekengi var. franchetii and can function as Michael reaction acceptors. Steroids 2012; 77(5): 441-447.

14. Zhang D, Ma X, Sun W, Cui P, Lu Z. Down-regulated FSTL5 promotes cell proliferation and survival by affecting $\mathrm{Wnt} / \beta$-catenin signaling in hepatocellular carcinoma. International Journal of Clinical \& Experimental Pathology 2015; 8(3): 3386-3394.

15. Naito S, von Eschenbach AC, Giavazzi R, Fidler IJ. Growth and metastasis of tumor cells isolated from a human renal cell carcinoma implanted into different organs of nude mice. Cancer research 1986; 46(8): 4109-4115.

16. Koo MY, Park J, Lim JM, Joo SY, Shin SP, Shim HB et al. Selective inhibition of the function of tyrosine-phosphorylated STAT3 with a phosphorylation site-specific intrabody. Proceedings of the National Academy of Sciences of the United States of America 2014; 111(17): 6269-6274.

17. Rubió L, Motilva MJ, Romero MP. Recent advances in biologically active compounds in herbs and spices: a review of the most effective antioxidant and anti-inflammatory active principles. Critical Reviews in Food Science and Nutrition 2013; 53(9): 943-953.

18. Gullett NP, Ruhul Amin AR, Bayraktar S, Pezzuto JM, Shin DM, Khuri FR et al. Cancer prevention with natural compounds. Paper presented at: Seminars in Oncology2010.

19. He H, Zang LH, Feng YS, Wang J, Liu WW, Chen LX et al. Physalin A induces apoptotic cell death and protective autophagy in HT1080 human fibrosarcoma cells. Journal of natural products 2013; 76(5): 880-888.

20. Shin JM, Lee KM, Lee HJ, Yun JH, Nho CW. Physalin A regulates the Nrf2 pathway through ERK and p38 for induction of detoxifying enzymes. BMC complementary and alternative medicine 2019; 19(1): 101.

21. He H, Zang LH, Feng YS, Chen LX, Kang N, Tashiro S et al. Physalin A induces apoptosis via p53-Noxa-mediated ROS generation, and autophagy plays a protective role against apoptosis through p38-NF-kappaB survival pathway in A375-S2 cells. Journal of ethnopharmacology 2013; 148(2): 544-555.

22. Chiang HC, Jaw SM, Chen CF, Kan WS. Antitumor agent, physalin F from Physalis angulata L. Anticancer research 1992; 12(3): 837-843.

23. Nagafuji S, Okabe H, Akahane H, Abe F. Trypanocidal constituents in plants 4. Withanolides from the aerial parts of Physalis angulata. Biological \& pharmaceutical bulletin 2004; 27(2): 193-197.

24. Wu SJ, Ng LT, Lin DL, Huang SN, Wang SS, Lin CC. Physalis peruviana extract induces apoptosis in human Hep G2 cells through CD95/CD95L system and the mitochondrial signaling transduction pathway. Cancer letters 2004; 215(2): 199-208. 
25. Wu SJ, Ng LT, Chen CH, Lin DL, Wang SS, Lin CC. Antihepatoma activity of Physalis angulata and P. peruviana extracts and their effects on apoptosis in human Hep G2 cells. Life sciences 2004; 74(16): 2061-2073.

26. Lee CC, Houghton P. Cytotoxicity of plants from Malaysia and Thailand used traditionally to treat cancer. Journal of ethnopharmacology 2005; 100(3): 237-243.

27. Choi JY, Lee SJ, Lee SJ, Park S, Lee JH, Shim JH et al. Analysis and tentative structure elucidation of new anthocyanins in fruit peel of Vitis coignetiae Pulliat (meoru) using LC-MS/MS: Contribution to the overall antioxidant activity. Journal of separation science 2010; 33(9): 1192-1197.

28. Darnell JE, Jr. STATs and gene regulation. Science 1997; 277(5332): 1630-1635.

29. Bromberg J, Darnell JE. The role of STATs in transcriptional control and their impact on cellular function. Oncogene 2000; 19(21): 2468-2473.

30. Liu J, Xu X, Feng X, Zhang B, Wang J. Adenovirus-mediated delivery of bFGF small interfering RNA reduces STAT3 phosphorylation and induces the depolarization of mitochondria and apoptosis in glioma cells U251. Journal of Experimental \& Clinical Cancer Research 2011; 30(1): 80.

31. Klemm JD, Schreiber SL, Crabtree GR. Dimerization as a regulatory mechanism in signal transduction. Annu Rev Immunol 1998; 16: 569-592.

32. Rane SG, Reddy EP. Janus kinases: components of multiple signaling pathways. Oncogene 2000; 19(49): 5662-5679.

33. Banerjee K, Resat $H$. Constitutive activation of STAT3 in breast cancer cells: A review. International journal of cancer Journal international du cancer 2016; 138(11): 2570-2578.

34. Alvarez JV, Greulich H, Sellers WR, Meyerson M, Frank DA. Signal Transducer and Activator of Transcription 3 Is Required for the Oncogenic Effects of Non-Small-Cell Lung Cancer-Associated Mutations of the Epidermal Growth Factor Receptor. Cancer research 2006; 66(6): 3162-3168.

35. Yin W, Cheepala S, Roberts JN, Sysonchan K, Digiovanni J, Clifford JL. Active Stat3 is required for survival of human squamous cell carcinoma cells in serum-free conditions. Molecular cancer 2006; 5(1): 15 .

36. Kusaba T, Nakayama T, Yamazumi K, Yakata Y, Yoshizaki A, Inoue K et al. Activation of STAT3 is a marker of poor prognosis in human colorectal cancer. Oncology reports 2006; 15(6): 1445-1451.

37. Morikawa T, Baba Y, Mai Y, Kuchiba A, Nosho K, Shima K et al. STAT3 Expression, Molecular Features, Inflammation Patterns and Prognosis in a Database of 724 Colorectal Cancers. Clinical Cancer Research An Official Journal of the American Association for Cancer Research 2011; 17(6): 1452-1462.

38. Jove, Richard. STAT proteins: novel molecular targets for cancer drug discovery. Expert opinion on therapeutic targets 2004; 8(5): 409-422.

39. Wang X, Crowe PJ, Goldstein D, Yang JL. STAT3 inhibition, a novel approach to enhancing targeted therapy in human cancers (review). International journal of oncology 2012; 41(4): 1181-1191.

40. CatlettFalcone, Robyn, Dalton, William S, Jove, Richard. STAT proteins as novel targets for cancer therapy. Current opinion in oncology 1999; 11(6): 490-496.

41. Gouilleux-Gruart V, Gouilleux F, Desaint C, Claisse JF, Capiod JC, Delobel J et al. STAT-related transcription factors are constitutively activated in peripheral blood cells from acute leukemia patients. Blood 1996; 87(5): 1692-1697.

42. WeberNordt RM, Egen C, Wehinger J, Ludwig W, GouilleuxGruart V, Mertelsmann R et al. Constitutive activation of STAT proteins in primary lymphoid and myeloid leukemia cells and in 
Epstein-Barr virus (EBV)-related lymphoma cell lines. Blood 1996; 88(3): 809-816.

43. Harada D, Takigawa N, Kiura K. The Role of STAT3 in Non-Small Cell Lung Cancer. Cancers 2014; 6(2): 708-722.

44. Catlett-Falcone R, Landowski TH, Oshiro MM, Turkson J, Levitzki A, Savino R et al. Constitutive activation of Stat3 signaling confers resistance to apoptosis in human U266 myeloma cells. Immunity 1999; 10(1): 105-115.

45. Hirano T, Nakajima K, Hibi M. Signaling mechanisms through gp130: a model of the cytokine system. Cytokine \& growth factor reviews 1997; 8(4): 241-252.

46. Tkach M, Rosemblit C, Rivas MA, Proietti CJ, Diaz Flaque MC, Mercogliano MF et al. p42/p44 MAPK-mediated Stat3Ser727 phosphorylation is required for progestin-induced full activation of Stat3 and breast cancer growth. Endocrine-related cancer 2013; 20(2): 197-212.

47. Aziz MH, Hafeez BB, Sand JM, Pierce DB, Aziz SW, Dreckschmidt NE et al. Protein kinase Cvarepsilon mediates Stat3Ser727 phosphorylation, Stat3-regulated gene expression, and cell invasion in various human cancer cell lines through integration with MAPK cascade (RAF-1, MEK1/2, and ERK1/2). Oncogene 2010; 29(21): 3100-3109.

48. Lin $\mathrm{H}$, Chen MC, Chiu CY, Song YM, Lin SY. Cdk5 regulates STAT3 activation and cell proliferation in medullary thyroid carcinoma cells. The Journal of biological chemistry 2007; 282(5): 2776-2784.

49. Kim JH, Kim JE, Liu HY, Cao W, Chen J. Regulation of interleukin-6-induced hepatic insulin resistance by mammalian target of rapamycin through the STAT3-SOCS3 pathway. The Journal of biological chemistry 2008; 283(2): 708-715.

50. Wakahara R, Kunimoto H, Tanino K, Kojima H, Inoue A, Shintaku H et al. Phospho-Ser727 of STAT3 regulates STAT3 activity by enhancing dephosphorylation of phospho-Tyr705 largely through TC45. Genes to cells : devoted to molecular \& cellular mechanisms 2012; 17(2): 132-145.

51. Shi $X$, Zhang $H$, Paddon $H$, Lee $G$, Cao X, Pelech S. Phosphorylation of STAT3 serine-727 by cyclin-dependent kinase 1 is critical for nocodazole-induced mitotic arrest. Biochemistry 2006; 45(18): 5857-5867.

52. Butturini E, Cavalieri E, de Prati AC, Darra E, Rigo A, Shoji K et al. Two naturally occurring terpenes, dehydrocostuslactone and costunolide, decrease intracellular GSH content and inhibit STAT3 activation. PloS one 2011; 6(5): e20174.

53. Ashkenazi A, Fairbrother WJ, Leverson JD, Souers AJ. From basic apoptosis discoveries to advanced selective BCL-2 family inhibitors. Nature reviews Drug discovery 2017; 16(4): 273-284 .

54. Schimmer AD, Welsh K, Pinilla C, Wang Z, Krajewska M, Bonneau MJ et al. Small-molecule antagonists of apoptosis suppressor XIAP exhibit broad antitumor activity. Cancer cell 2004; 5(1): 25-35.

55. Boulares AH, Yakovlev AG, Ivanova V, Stoica BA, Wang G, lyer $S$ et al. Role of poly(ADP-ribose) polymerase (PARP) cleavage in apoptosis. Caspase 3-resistant PARP mutant increases rates of apoptosis in transfected cells. The Journal of biological chemistry 1999; 274(33): 22932-22940.

\section{Table legends}

Table 1. IC50 values of the Physalis alkekengi var. franchetii extracts $(\mu \mathrm{g} / \mathrm{ml}, 24 \mathrm{~h}$ treated) for seven human tumour cell lines. 


\section{Figure Legends}

Figure 1. The main extracts of Physalis alkekengi var. franchetii. (A) Chemical structures of the physalins extracted from Physalis alkekengi var. franchetii. (B) UPLC and total ion current chrematogram. Peaks: 1=physalin A, 2= isophysalin A, 3= physalin $\mathrm{O}, 4=$ physalin $\mathrm{L}$ and $5=$ physalin $\mathrm{G}$.

Figure 2. Cell viability of human tumour cell lines in the presence of the Physalis alkekengi var. franchetii extracts. Various doses of physalins $(0,2.5,5,10,15,20$ and $30 \mu \mathrm{g} / \mathrm{mL}$ ) treated cells for $24 \mathrm{~h}(\mathrm{~A})$ or $48 \mathrm{~h}(\mathrm{~B})$. CCK8 assays were performed to examine the cell viability.

Figure 3. Physalis alkekengi var. franchetii extracts suppress the constitutive and IL-6 induced STAT3 Tyr705 phosphorylation in NCI-H1975 and U266 cells. (A) NCI-H1975 cells were treated for $4 \mathrm{~h}$ with physalins $(0,5,10,15 \mu \mathrm{g} / \mathrm{mL})$. The levels of p-STAT3-Tyr, p-STAT3-Ser, STAT3 and $\beta$-actin were detected by a Western blot analysis. (B) U266 cells were treated for $4 \mathrm{~h}$ with physalins in a dose-dependent manner. The cell lysates were subjected to a Western blot analysis using antibodies specific for p-STAT3-Tyr, p-STAT3-Ser, STAT3 and $\beta$-actin. The semi-quantification of protein levels were performed by Image $\mathrm{J}$ software. The relative gray values of p-STAT3-Tyr were shown below. (C) The physalins suppressed p-STAT3 nuclear translocation. H1975 cells were treated with $15 \mu \mathrm{g} / \mathrm{ml}$ of physalins for $6 \mathrm{~h}$ with or without $25 \mathrm{ng} / \mathrm{mL}$ of IL-6. The immunofluorescence analysis was performed with a p-STAT3-Tyr primary antibody followed with an anti-rabbit IgG Fab 2Alexa Fluor 555 antibody. Coverslipped slides were covered with Anti-fade reagents with DAPI. The merged images show the overlay of the red Alexa Fluor 555 and the blue DAPI fluorescence.

Figure 4. Physalis alkekengi var. franchetii extracts suppress STAT3-mediated downstream genes in NCI-H1975 and U266 cells. (A) NCI-H1975 cells were incubated with various concentrations of physalins for $24 \mathrm{~h}$. The cell lysates were isolated for a Western blot analysis to detect the Bcl-2 family, XIAP and survivin protein levels. $\beta$-actin was used as a loading control. (B) U266 cells were treated with physalins in a dose-dependent manner for $24 \mathrm{~h}$. A Western blot was performed with the Bcl-2 family, XIAP and surviving primary antibodies. The semi-quantification of protein levels were performed by Image $\mathrm{J}$ software. The relative gray values of Bcl-2 and XIAP were shown below.

Figure 5. Physalis alkekengi var. franchetii extracts induce apoptosis in NCI-H1975 and U266 cells. (A) NCI-H1975 cells and (B) U266 cells were treated with different concentrations of physalins for $24 \mathrm{~h}$, and then, the cells were collected and labelled with Annexin V-FITC/PI followed by the flow cytometric analysis. (C) NCI-H1975 cells and (D) U266 cells were treated physalins in a dose-dependent manner for $24 \mathrm{~h}$. A Western blot was performed with cleaved caspase-9, cleaved 
caspase-3 and PARP antibodies.

Figure 6. Physalis alkekengi var. franchetii extracts inhibit tumour growth in a human NSCLC xenograft model. (A) Tumour volumes were measured at the indicated times using Verniercallipers. Tumour volume $=$ length $\times$ width $^{2} / 2$. ** for $P<0.01$ and $* * *$ for $P<0.001$. The $\mathrm{P}$ values were analyzed by ANOVA with post hoc test. (B) After 10 days, all the mice were sacrificed, and the tumours were arranged and photographed. (C) The average tumour weights were analysed in each group. The statistical analysis was done by student t-test, ** for $P<0.01$ and $* * *$ for $P<0.001$. (D) The body weights were measured at the indicated times. 
Figures

A
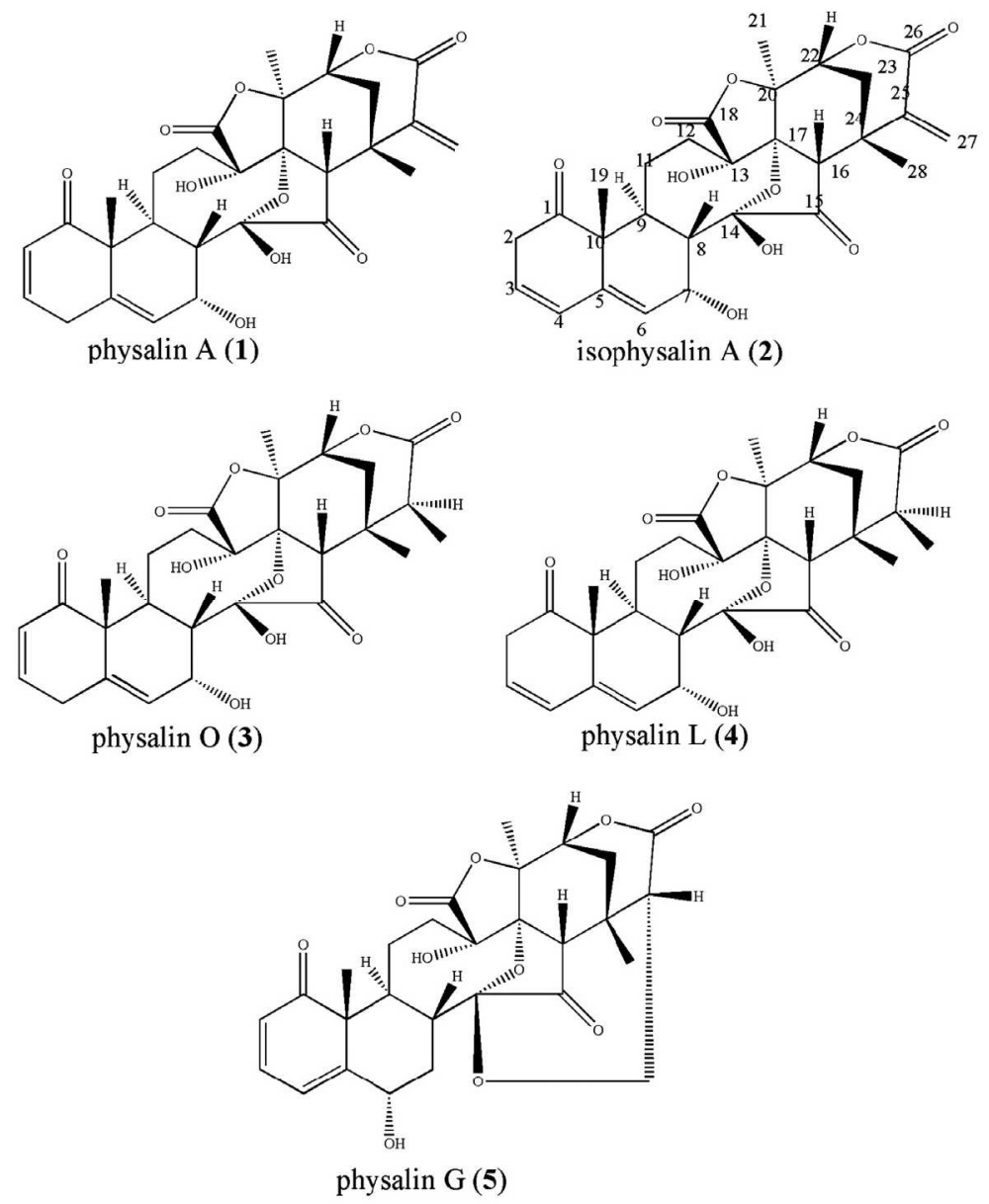

B

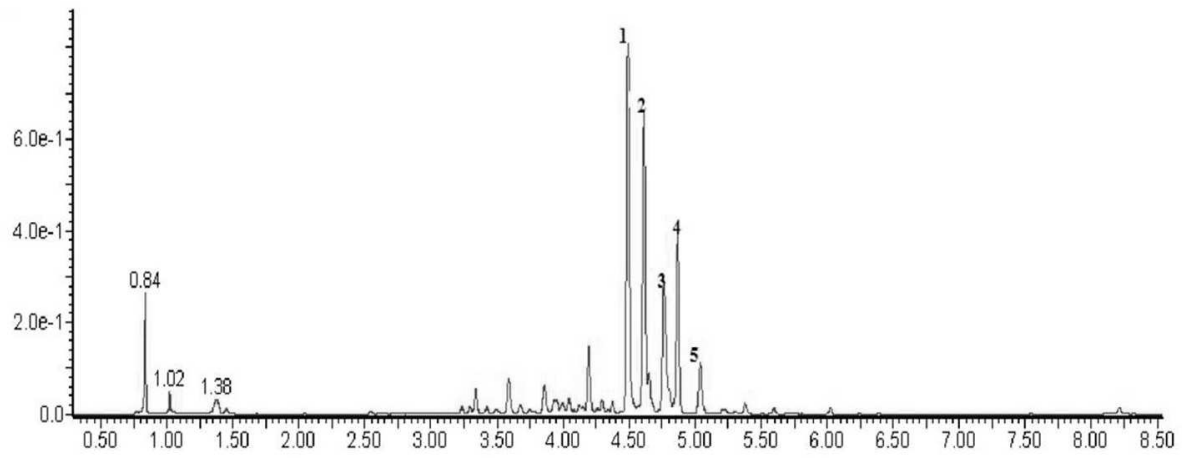

\section{Figure 1}

The main extracts of Physalis alkekengi var. franchetii. (A) Chemical structures of the physalins extracted from Physalis alkekengi var. franchetii. (B) UPLC and total ion current chrematogram. Peaks: 1=physalin A, 2= isophysalin $A, 3=$ physalin $0,4=$ physalin $L$ and $5=$ physalin $G$. 


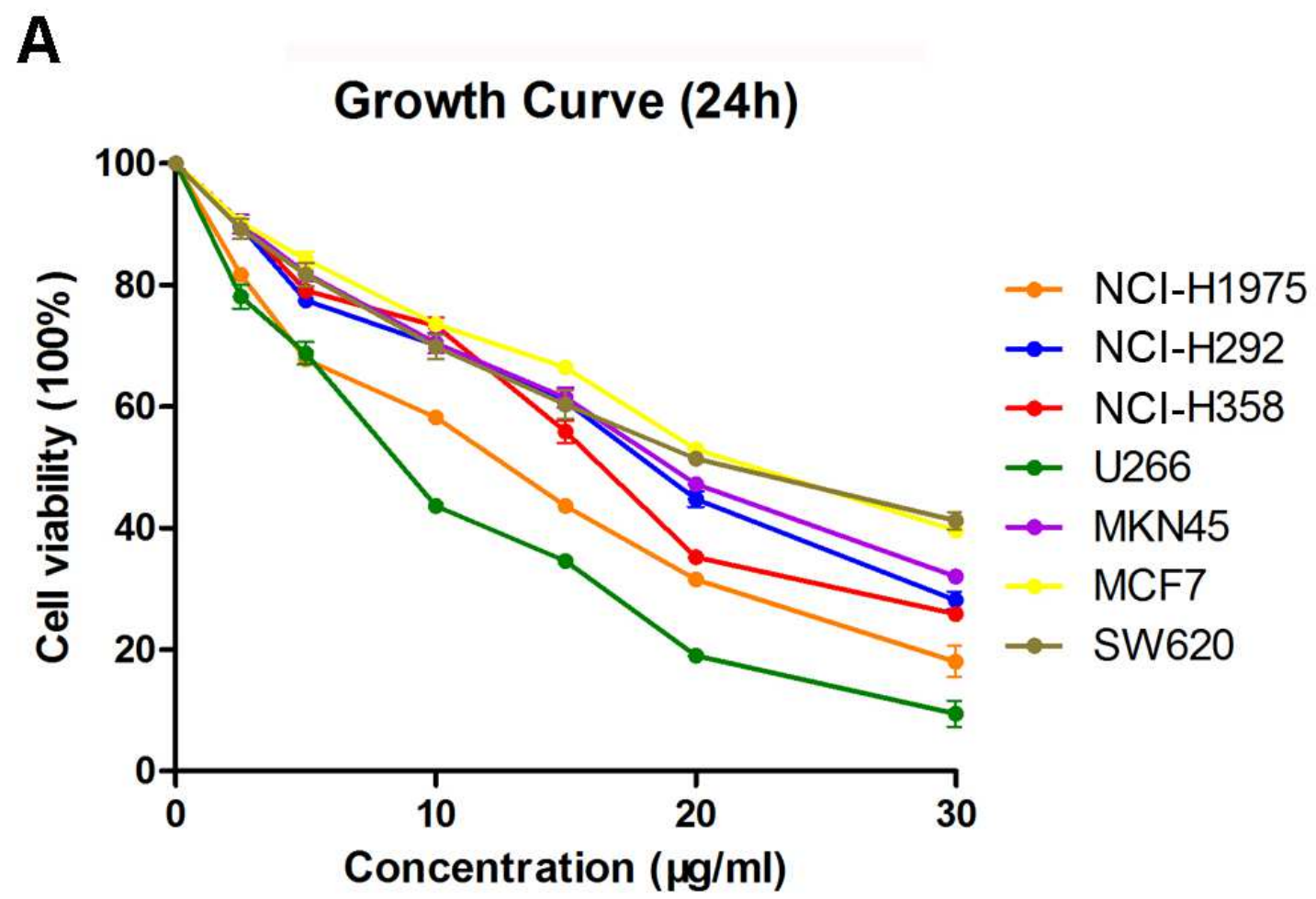

B

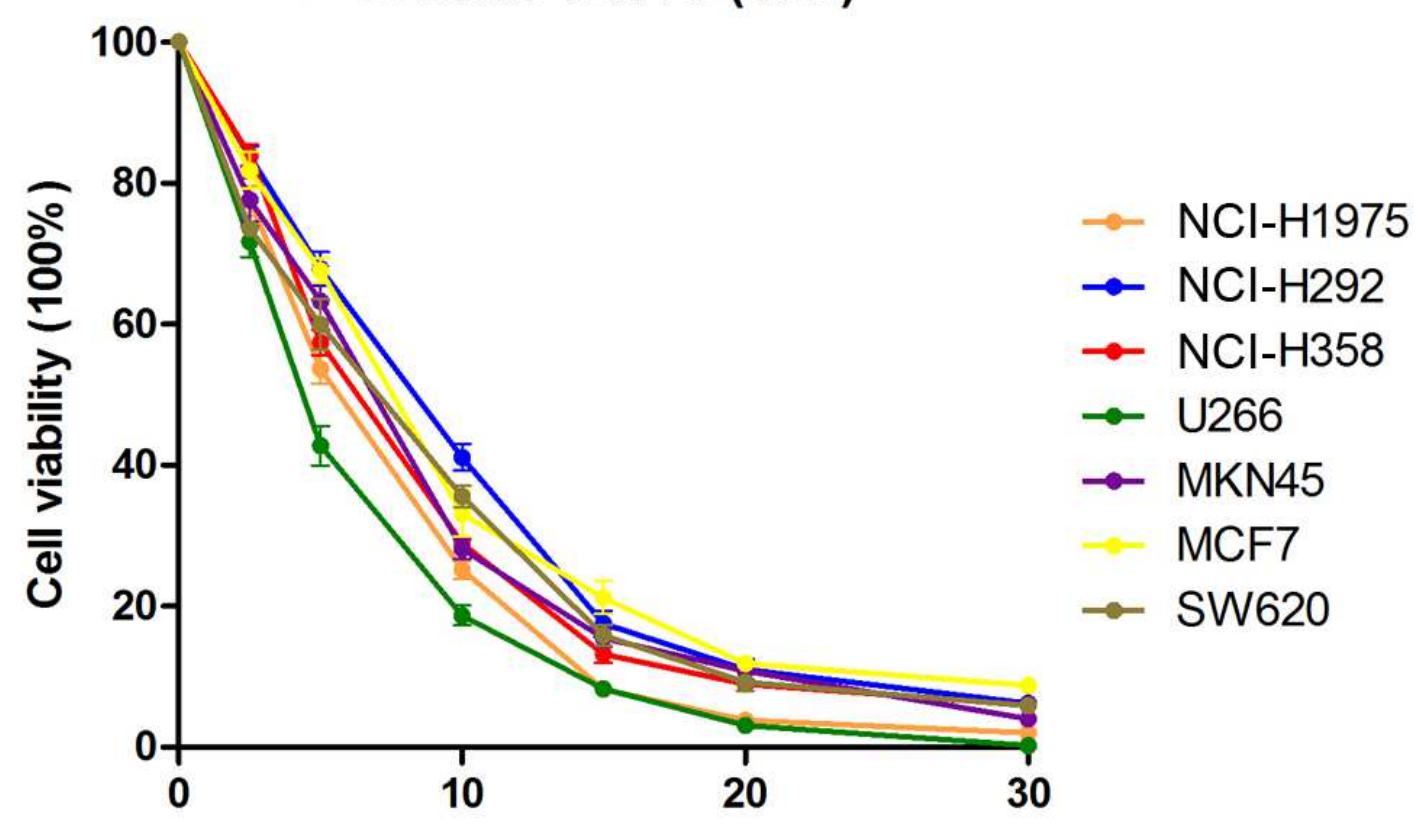

Figure 2

Cell viability of human tumour cell lines in the presence of the Physalis alkekengi var. franchetii extracts. Various doses of physalins $(0,2.5,5,10,15,20$ and $30 \mu \mathrm{g} / \mathrm{mL})$ treated cells for $24 \mathrm{~h}(\mathrm{~A})$ or $48 \mathrm{~h}(\mathrm{~B})$. CCK8 assays were performed to examine the cell viability. 
A

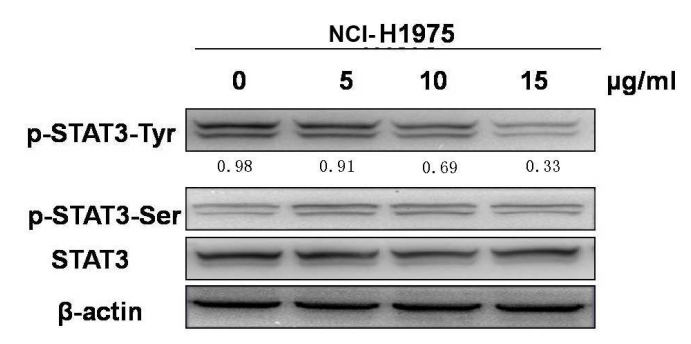

B

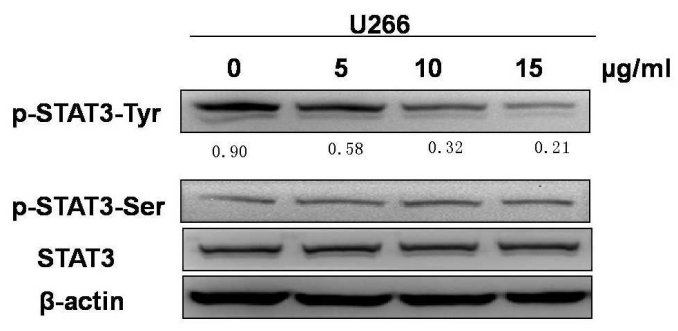

C

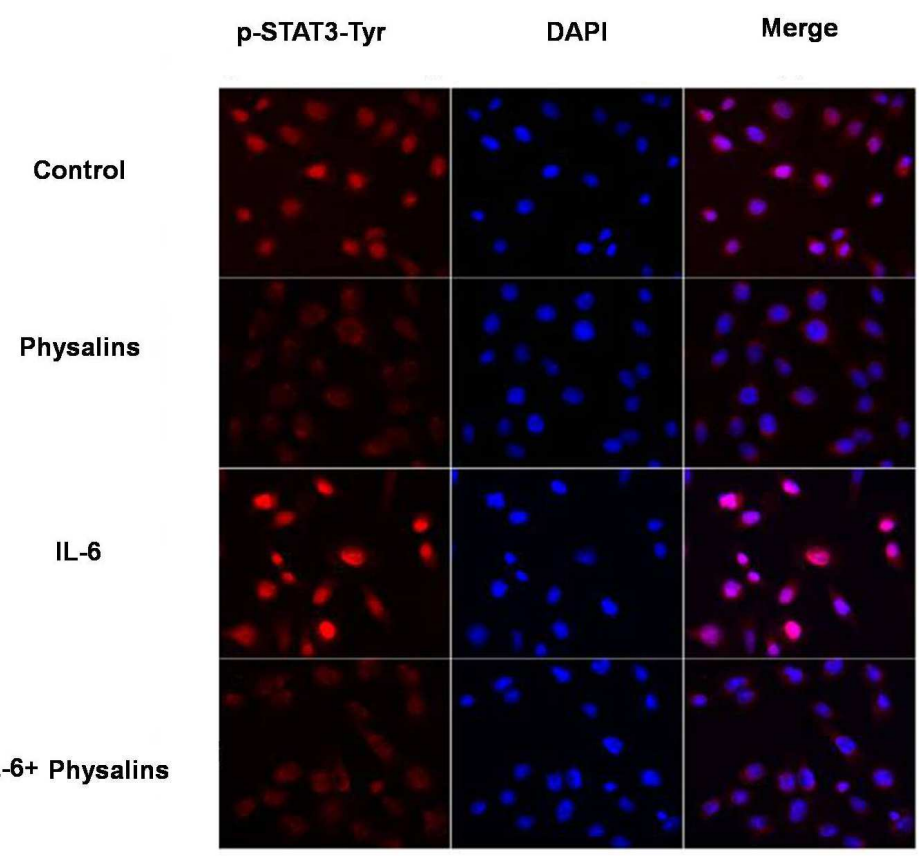

\section{Figure 3}

Physalis alkekengi var. franchetii extracts suppress the constitutive and IL-6 induced STAT3 Tyr705 phosphorylation in NCl-H1975 and U266 cells. (A) NCl-H1975 cells were treated for $4 \mathrm{~h}$ with physalins (0, $5,10,15 \mu \mathrm{g} / \mathrm{mL}$ ). The levels of p-STAT3-Tyr, p-STAT3-Ser, STAT3 and $\beta$-actin were detected by a Western blot analysis. (B) U266 cells were treated for $4 \mathrm{~h}$ with physalins in a dose-dependent manner. The cell lysates were subjected to a Western blot analysis using antibodies specific for p-STAT3-Tyr, p-STAT3-Ser, STAT3 and $\beta$-actin. The semi-quantification of protein levels were performed by Image $\mathrm{J}$ software. The relative gray values of p-STAT3-Tyr were shown below. (C) The physalins suppressed p-STAT3 nuclear translocation. $\mathrm{H} 1975$ cells were treated with $15 \mu \mathrm{g} / \mathrm{ml}$ of physalins for $6 \mathrm{~h}$ with or without $25 \mathrm{ng} / \mathrm{mL}$ of IL6. The immunofluorescence analysis was performed with a p-STAT3-Tyr primary antibody followed with an anti-rabbit IgG Fab 2Alexa Fluor 555 antibody. Coverslipped slides were covered with Anti-fade reagents with DAPI. The merged images show the overlay of the red Alexa Fluor 555 and the blue DAPI fluorescence. 
A

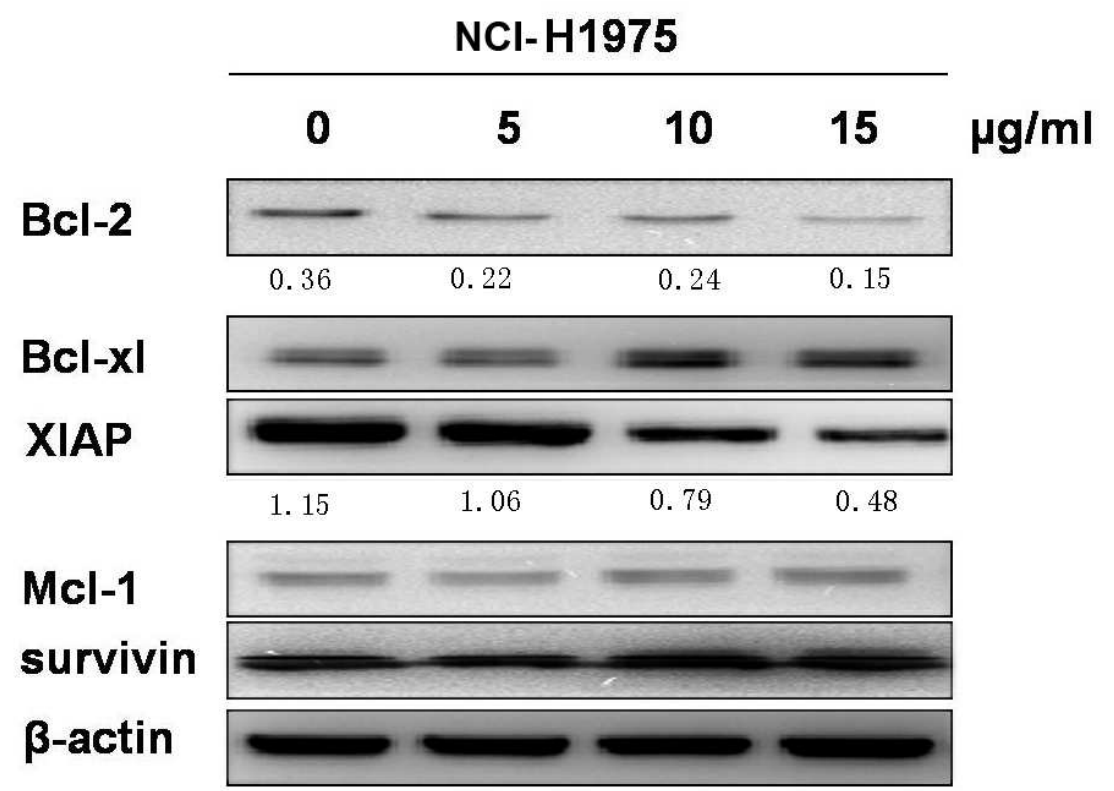

B

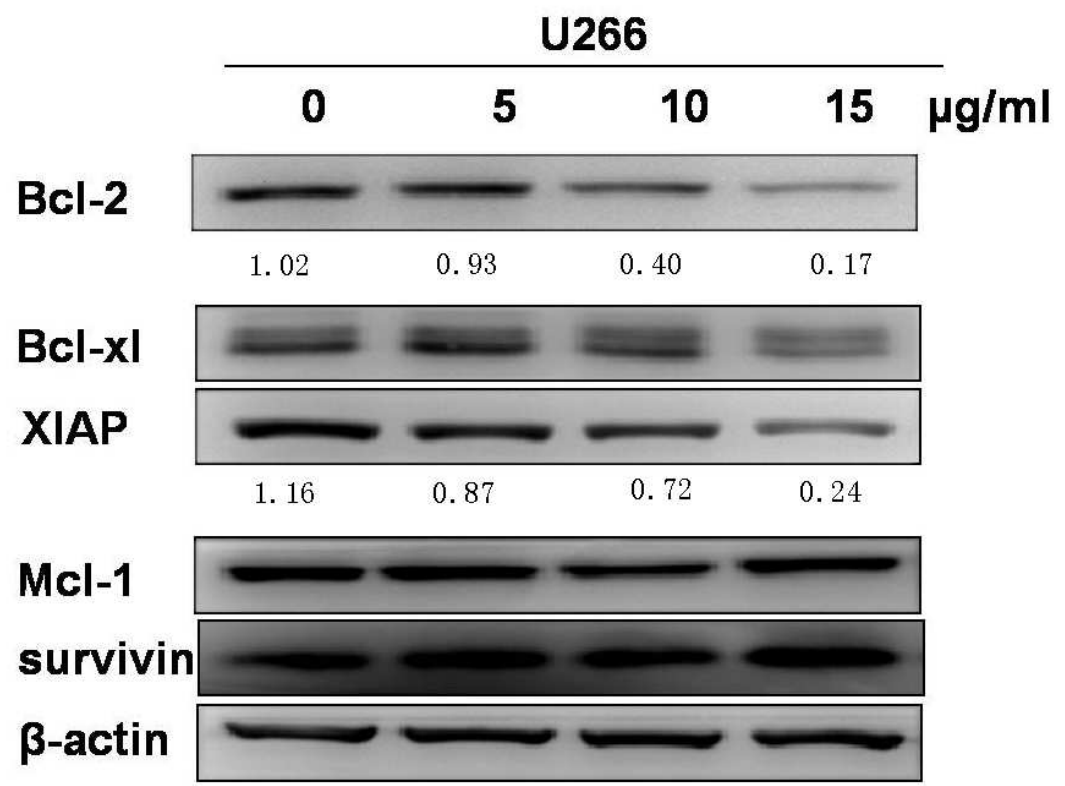

Figure 4

Physalis alkekengi var. franchetii extracts suppress STAT3-mediated downstream genes in NCI-H1975 and $\mathrm{U} 266$ cells. (A) NCl-H1975 cells were incubated with various concentrations of physalins for $24 \mathrm{~h}$. The cell lysates were isolated for a Western blot analysis to detect the Bcl-2 family, XIAP and survivin protein levels. $\beta$-actin was used as a loading control. (B) U266 cells were treated with physalins in a dosedependent manner for 24h. A Western blot was performed with the Bcl-2 family, XIAP and surviving 
primary antibodies. The semi-quantification of protein levels were performed by Image $\mathrm{J}$ software. The relative gray values of Bcl-2 and XIAP were shown below.

A

NCI-H1975

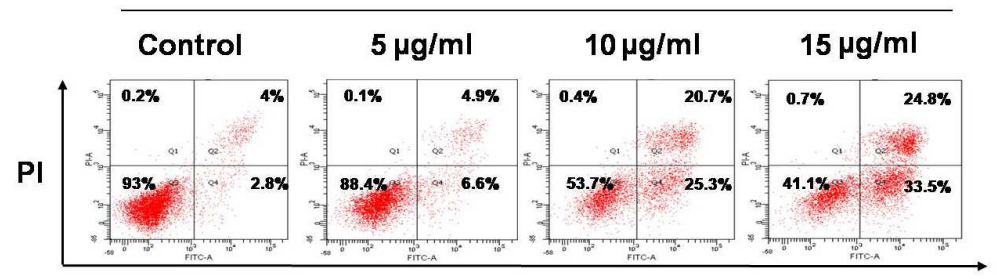

Annexin V-FITC

B

U266

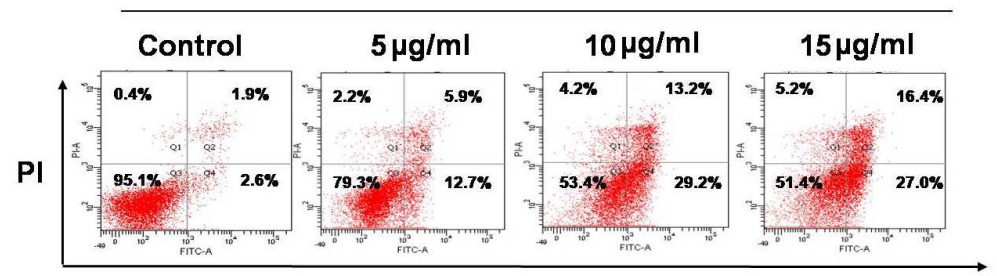

Annexin V - FITC

C

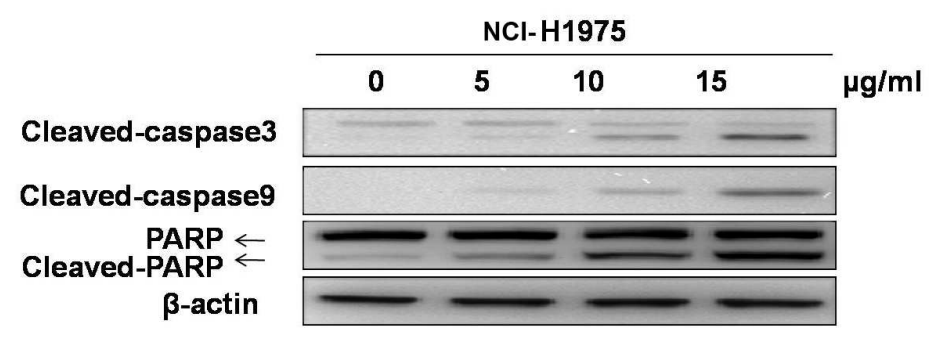

D

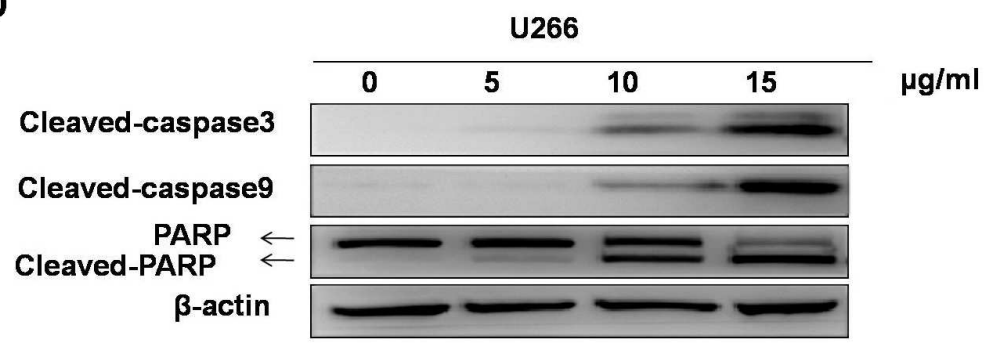

\section{Figure 5}

Physalis alkekengi var. franchetii extracts induce apoptosis in NCl-H1975 and U266 cells. (A) NCl-H1975 cells and (B) U266 cells were treated with different concentrations of physalins for $24 \mathrm{~h}$, and then, the cells were collected and labelled with Annexin V-FITC/PI followed by the flow cytometric analysis. (C) $\mathrm{NCl}$ 
H1975 cells and (D) U266 cells were treated physalins in a dose-dependent manner for $24 \mathrm{~h}$. A Western blot was performed with cleaved caspase-9, cleaved caspase-3 and PARP antibodies.

A

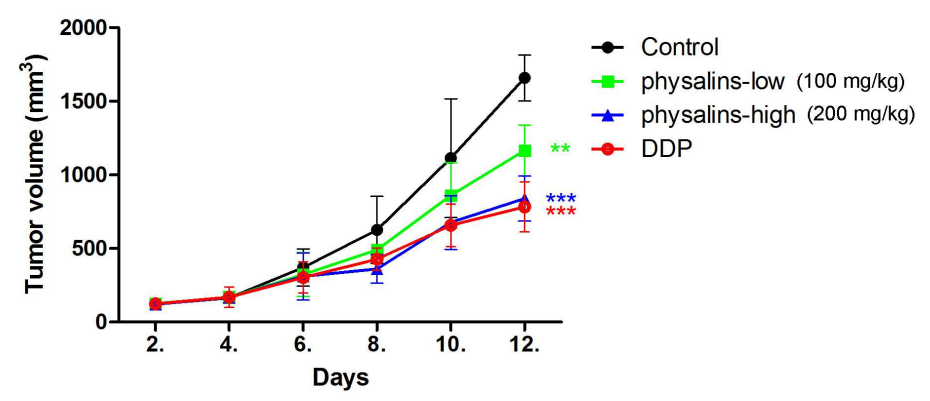

B

Control

physalins-low $(100 \mathrm{mg} / \mathrm{kg})$ physalins-high $(200 \mathrm{mg} / \mathrm{kg})$ DDP

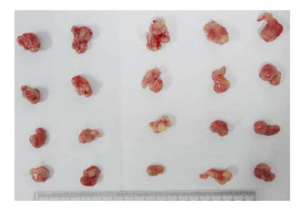

C

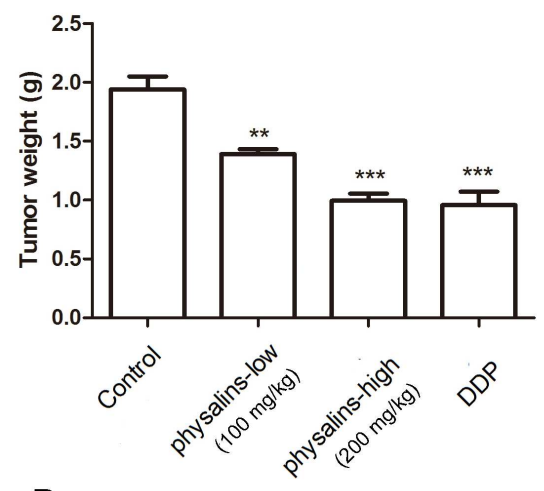

D

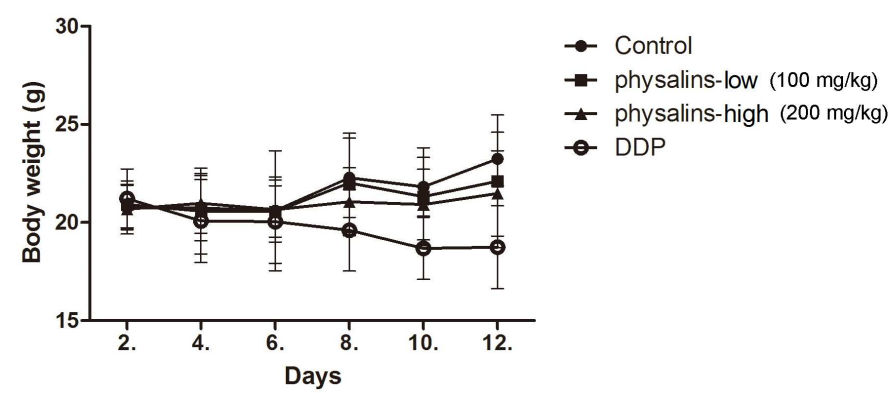

\section{Figure 6}

Physalis alkekengi var. franchetii extracts inhibit tumour growth in a human NSCLC xenograft model. (A) Tumour volumes were measured at the indicated times using Verniercallipers. Tumour volume $=$ length $x$ width2/2. ** for $P<0.01$ and $* \star \star$ for $P<0.001$. The $P$ values were analyzed by ANOVA with post hoc test. (B) After 10 days, all the mice were sacrificed, and the tumours were arranged and photographed. (C) The average tumour weights were analysed in each group. The statistical analysis was done by student t-test, $\star \star$ for $P<0.01$ and $* \star \star$ for $P<0.001$. (D) The body weights were measured at the indicated times.

\section{Supplementary Files}

This is a list of supplementary files associated with this preprint. Click to download.

- Supplementarytable1.docx 